\title{
Fraud Hexagon and Fraudulent Financial Statement: Comparison Between OMI and Beneish Model
}

\author{
*Dwiyanjana Santyo Nugroho ${ }^{1}$, Vera Diyanty ${ }^{2}$
}

\author{
${ }^{1}$ Faculty of Economics and Business, Universitas Indonesia \\ ${ }^{2}$ Faculty of Economics and Business, Universitas Indonesia \\ *Corresponding author.Email: santyonug@gmail.com
}

\begin{abstract}
The leading cause of financial statement fraud (FFS) is a "poor tone" carried out by top parties. This study examines the effect of elements in Hexagon Fraud on FFS. This study uses logistic regression analysis and a random effect regression model. The data used are all non-financial companies in Indonesia in 2016-2020. We compare the accuracy of the M-score findings using the Overall Manipulation Index (OMI) approach. The results showed slightly different findings when FFS was measured using two different measurements. Rationalization is proven to affect the occurrence of FFS; both measured using the M-score and OMI. Stimulus and opportunity partially influence the occurrence of FFS. This study also demonstrates which elements in the financial statements are often used as a tool to perform FFS and finds evidence that DEPI is the item most frequently used to perform FFS. On the other hand, the sector that is indicated to conduct FFS often is the cyclical consumer sector.
\end{abstract}

Keywords: Hexagon Fraud, Overall Manipulation Index, Fraudulent Financial Statement.

\section{INTRODUCTION}

PWC's Global Economic Crime and Fraud Survey [1] states that $47 \%$ of respondents admit that their company has experienced fraud in the last 24 months, the second-highest percentage in the previous 20 years. Another finding in the survey also found that bribery, corruption, and accounting fraud cases experienced a relatively rapid increase in 2020 . Among various types of fraud, financial reporting is an area of great concern for potential investors, audits, and state regulators [2].

The Survey Report to the Nation 2020 [3] found that the Asia-Pacific region has an immense median loss impact worldwide due to fraud. Indonesia has the most fraud cases in the Asia-Pacific region. Indonesia is a country that faces the most fraud cases compared to other countries with 36 instances, surpassing China which is in second place with 33 fraud cases in the Asia-Pacific region. Based on the survey, FFS is a type of fraud that causes a tremendous loss compared to other kinds of fraud.
FFS has the potential to be carried out in various industrial sectors of the company. From the retail industry sector, there is an allegation that PT. Tiga Pilar Sejahtera Food Tbk committed fraud in the 2017 financial statements from the real estate industry sector, PT. Hanson International was proven to have conducted FFS, which caused it to be overstated, and [4] has specifically proven the financial problems Garuda Indonesia experienced and found that there were during 2007 - 2018 restatements that were in line with indications as a signal of FFS.

The evolution of fraud theory has moved the current view of fraud far beyond simplicity, where it occurs systematically with the determinants of collusion or cooperation from various parties. Hexagon or SCCORE model introduced by [5]. The emergence of the Hexagon Fraud model provides an opportunity to prove the alignment of the model with fraudulent practices that occur. Cousins [5] argues that the models in Fraud Theory need to be updated to adapt to the latest developments in the field and $\mathrm{t} h \mathrm{e}$ growing incidence of fraud. 
Most hexagon frauds were tested in public sector organizations [6][7][8]; only [9] examined publicly listed companies on the stock exchange. The difference is, this study examines all industrial sectors of companies listed on the Indonesia Stock Exchange (IDX) while [9] only examines the banking sector.

The main contribution and the novelty of this research is further research on the use of the M-score by using the Overall Manipulation Index (OMI), which is considered to distinguish manipulator companies better [16] use OMI to rank fraud that occurs in various industrial sectors, while in this study, OMI is used to strengthen the findings obtained from the M-Score measurement. The M-score model is a probability model, which cannot detect manipulation $100 \%$ [10]. Therefore, many researchers adopt the model's construct to the conditions in their respective countries [11], [12], [13], [14]. Meanwhile, in Indonesia, no research has adjusted the construct of the M-score model. This causes the M-score research findings to show often more inaccuracies in detecting fraud than other models [4], [10], [15].

The management option in committing fraud involving other parties is manipulating related party transactions (RPT). This study develops the findings of [17], which first uses the ratio of RPT transactions in accounts receivable to total receivables as the potential for FFS. The findings of [17] only look at a small part of the RPT, while this study wants to examine the entire RPT owned by the company so that it has a broader picture to explain whether the company's RPT causes FFS. In addition, there are still some less accurate findings in previous studies. [18], [19], [20], and [17] view that pressure only comes from the company's financial targets, while [21] states that the existence of free cash flow (FCF) causes management to be pressured to manage the money, causing management to conduct FFS. Therefore, this study measures the stimulus using how much FCF management has. In addition, several studies have similar findings that ego cannot influence management behaviour to commit financial statement fraud. Cousins [5] stated that arrogance is the main element that plays a vital role in forcing people to commit fraud. However, previous findings [19], [20], [21] do not prove the accuracy of arrogance in influencing FFS. So, this study follows the ego measurement conducted by [22]. The subsequent discussion successively discusses literature review and development of hypotheses, methods, findings, and conclusions.

\section{LITERATURE REVIEW}

\subsection{Upper Echelon Theory}

The upper echelon theory was coined by [23], which states that organizational outcomes, both in the form of strategic choices and level of performance, are partly predicted by the characteristics of managerial background. The central premise of upper echelon theory is that executives' experiences, values, and personalities greatly influence their interpretation of the situations they face and, in turn, influence their choices [24]. Furthermore, suppose much managerial discretion is present. In that case, organizational characteristics will be reflected in strategy and performance, but executive factors are not very important if there is less discretion. Executives under demanding jobs will be forced to cut corners or go back to what they have tried, which means their choices will reflect their background and character.

\subsection{Literature Review and Hypothesis Development}

The fraud Theory model continues to evolve to explain how someone, or in this case is management, commits fraud. Fraud models seek to identify additional psychological or sociological antecedents (personality and behavioral characteristics) to describe those prone to fraud [25]. Several models and theories of fraud have been extended and explain why individuals commit fraud and financial crimes beyond the reasons given by the Fraud Triangle [26]. The fraud pentagon model was developed into a fraud hexagon by [5] by adding an element of collusion. This model has the acronym S.C.C.O.R.E which consists of stimulus, capability, collusion, opportunity, rationalization, ego.

Agency theory states that the conflict of interest between management and stakeholders is related to the existence of FCF. The more FCFs, the more likely it is that FFS will occur. If the company's FCF is not used or invested to maximize and balance the interests of all shareholders, it leads to the emergence of agency problems [27]. Moreover, the existence of FCF will open up opportunities for management to conduct FFS; management is always looking for high profits with excess money [21], [28]. Cash flow that is not used to run the company can stimulate directors to use it personally and manipulate financial statements.

H1: The stimulus has a positive effect on FFS.

Capability refers to the ability of management to manage or lead the company. Many FFS cases would not have occurred without the right people with the right skills implementing the details of the fraud [5]. Changes in management/director associations can reflect how the company's stress management is 
managed. The evolution of directors can indicate a particular political interest to replace the previous board of directors. Changes in the board of directors can be used to get rid of those who hinder the company's fraud. This happens because the fraud hexagon assumes that fraud is carried out in groups, where there is an agreement between managers to carry out FFS. Managers can engineer decisions by relying on power to eliminate conflicting parties, making it easier for management to carry out FFS [17], [20].

\section{H2: The capability has a positive effect on FFS.}

Opportunity in this context refers to the lack of control functions within the organization so that perpetrators who initially did not intend to commit fraud can eventually commit fraud [29]. Companies with a weak internal control system will h a v e many gaps that become opportunities for management to regulate transactions, especially financial transactions, as presented in financial statements [30]. Opportunities to commit fraud can be caused by strategic economic posts making it easy to commit fraud. In addition, there can be misstatements or mismeasurements and recognition in the financial statements. The high value of receivables on sales shows that receivables are assets that have a higher risk of manipulation [21], [31]. The larger the accounts receivable that can be used for manipulation, the greater the tendency for FFS to occur.

H3: The opportunity has a positive effect on FFS.

Rationalization is a justification that appears in the perpetrator's mind when committing fraud [32]. Fraud perpetrators rationalize to protect themselves from all accusations that will later lead to them, namely with the perception that the fraud committed is not a violation but something natural to do. External auditors generally find violations in financial statements. The relationship between management and auditors is management rationalization because auditor observations affect audit risk and results, raising management concerns [17]. Changes in auditors can be associated as a form to eliminate traces of fraud found by previous auditors. The more often the company changes auditors, the more likely it is that management will perform FFS [17], [33], [34].

H4: Rationalization has a positive effect on FFS.

Ego or arrogance is an attitude of superiority or greed from people who believe that internal control does not apply personally [35]. Ego can also be associated with a person's narcissism. Narcissists are generally overconfident about their abilities, with an unrestricted desire for power and success, which leads them to increase their pay rates [36]. Directors who are narcissistic and have big egos have self-confidence that makes them ask for more excellent compensation from the company. Directors can use their position of authority and influence to achieve their personal and economic ambitions, where the more significant the compensation they receive, the more likely they are to engage in FFS [22], [37].

H5: The arrogance of directors has a positive effect on FFS.

According to [5], collusion refers to a deceptive or compact agreement between two or more people, for one party to take action on the other for some unfavorable purpose, such as to defraud a third party of their rights. Collusion occurs because there is more than one party to deceive or take advantage of company mechanisms, one of which is the existence of transactions within the company. Large companies usually circumvent the transfer of management wealth through subsidiaries, which are listed in the RPT. The presence of RPT can be used to carry out wealth laundering so that the amount of RPT, if it does not make sense, which can be seen from its operations, is it related to subsidiaries so that it can be tracked when there is fraud in the RPT. This measurement has never been carried out in other studies to measure collusion, but we refer to [38]. They found that RPT influences the company's decision to tend to appoint non-Big 4 auditors. This is quite relevant if it is related to collusion, which means that companies with large RPT tend to collude between companies and their affiliates, which ultimately causes FFS.

H6: Collusion has a positive effect on FFS.

\section{RESEARCH METHODS}

The population in this financial research are all non - institutional companies listed on the Indonesia stock exchange (IDX). The research conducted was from 2016 - 2020. This research covers all industrial sectors because it anticipates the FFS detection model, which cannot detect it $100 \%$. The sample selection method used is purposive sampling, where the acquisition of samples with criteria, then obtained the number of samples listed in table 1:

Table 1. The acquisition of samples

\begin{tabular}{|l|c|}
\hline \multicolumn{1}{|c|}{ Criteria } & Amount \\
\hline Non-financial companies & 621 \\
\hline $\begin{array}{l}\text { Non-financial companies listed on } \\
\text { the IDX in 2016-2020 }\end{array}$ & $(198)$ \\
\hline $\begin{array}{l}\text { Have consecutive annual reports } \\
\text { and published to the public }\end{array}$ & $(14)$ \\
\hline $\begin{array}{l}\text { The company did experience } \\
\text { delisting suspension during the } \\
\text { study period }\end{array}$ & \\
\hline
\end{tabular}




\begin{tabular}{|l|l|}
\hline $\begin{array}{l}\text { The company has complete data } \\
\text { according to what is needed in the } \\
\text { research }\end{array}$ & (38) \\
\hline Total & 350 firms \\
\hline
\end{tabular}

The total sample obtained is based on Table 1 in 350 companies with a research period of $2016-2020$. The data needed in this study are financial and nonfinancial data that are secondary data, where the required information is available in the company's annual report. The company's annual report is downloaded through the IDX website or its website if it is not available on the IDX. The statistical tool used is STATA version 16 .

Regression analysis and hypothesis testing used were logistic regression and ordinal least square (OLS) regression because this study had two dependent variables to measure FFS, one of which was dummy data, while the rest used panel data. Data quality tests were conducted for all models to determine which model is the best for interpreting the findings in this study. Model1 uses logistic regression, while model 2 uses OLS. The regression equation of this study consists of:

$\mathrm{FFS}_{\mathrm{t}, \mathrm{t}}$ $\alpha+\beta_{1} \mathrm{STI}_{\mathrm{i}, \mathrm{t}}+\beta_{2} \mathrm{KAP}_{\mathrm{i}, \mathrm{t}}+\beta_{3} \mathrm{PEL}_{\mathrm{i}, \mathrm{t}}+\beta_{4} \mathrm{RAS}_{\mathrm{i}, \mathrm{t}}+\beta_{5} \mathrm{ARO}_{\mathrm{i}, \mathrm{t}}+\beta_{6}$ $\mathrm{KOL} i,++\beta_{7}$ control $+\varepsilon$

$\mathrm{OMI}_{\mathrm{i}, \mathrm{t}}=$ $\alpha+\beta_{1} \mathrm{STI}_{\mathrm{i}, \mathrm{t}}+\beta_{2} \mathrm{KAP}_{\mathrm{i}, \mathrm{t}}+\beta_{3} \mathrm{PEL}_{\mathrm{i}, \mathrm{t}}+\beta_{4} \mathrm{RAS}_{\mathrm{i}, \mathrm{t}}+\beta_{5} \mathrm{ARO}_{\mathrm{i}, \mathrm{t}}+\beta_{6} \mathrm{~K}$ $\mathrm{OL}_{\mathrm{i}, \mathrm{t}}+\beta_{7}$ control $+\varepsilon$

Description:

- $\mathrm{OMI}=$ Overall Manipulation Index

- FFS = Fraudulent financial statement $(\mathrm{M}-$ score)

- $\mathrm{a}=$ Constanta

- $\beta=$ Coefficient regression

- STI = stimulus

- $\mathrm{KAP}=$ capability

- PEL = opportunity

- RAS = rationalization

- $\mathrm{ARO}=$ arrogance/ego

- $\mathrm{KOL}=$ collusion

- Control = variable control

- $\mathrm{e}=$ error

Where DSR is the daily sales index in accounts receivable; GMI is a gross margin index; $\mathrm{AQI}$ is an index of asset quality; SGI is an asset growth index; DEPI is a depreciation index; SGAI is an index of administrative, general, and selling expenses; ACCRUAL is the index of total accruals to total assets, and LEVI is a leverage index. The results of the Mscore calculation will produce two categories which make it a dummy variable. Companies that are indicated to be doing FFS will be given a code of 1, and companies that are not indicated to be doing FFS will be given a code of 0 . In the second stage, the Mscore component obtained is assessed based on a predetermined threshold, as done by [16]. The OMI threshold for DSR is 1.031; GMI is 1.014; AQI is 1,039; SGI is 1.134; DEPI is 1.001; SGAI 1,054; ACCRUAL is 0.018; LEVI is 1037. Each value in each component that exceeds the specified threshold is assigned a value of 1 , which means that the element indicates the presence of FFS. So, to obtain the OMI value, the number of elements in the M-score that exceeds the benchmark obtained is divided by the total available elements.

This study makes improvements to several measurements of elements in the fraud hexagon, which follow [19], [21], [22], and [38]. The elements in the fraud hexagon are measured as follows: stimulus is measured using FCF [21]; capability is measured using the change of directors, the opportunity is measured using the ratio of receivables to sales, rationalization is measured using auditor turnover [39]; arrogance is measured using the natural logarithm of directors' remuneration [22], and collusion is measured using the ratio of total R PT to equity [38].

\section{RESULT AND DISCUSSION}

Model 1 uses the logit model for more than probit based on fitstat assessment into the analysis. In contrast, model 2 random effect model (REM) is based on the Hausman Test and Brush-Pagan Lagrangian comparison, which is the basis for selecting the most appropriate model [40]. The heteroscedasticity test was not carried out because, in the REM analysis, the regression used was GLS Regression which had answered or eliminated the heteroscedasticity problem. In addition, there is no multicollinearity problem in the observational data of this study, where the VIF value is less than 10 . In model 1 , it is necessary to perform a diagnostic test with sensitivity and specificity parameters. These two parameters have a constant value, the same value wherever the discriminatory test is carried out. Table 2 shows the test where the sensitivity value in model 1 is $62.10 \%$, meaning that the research model can detect subjects who respond not too high. In addition, this research model can detect unresponsive subjects, which can be seen from the specificity value of $84.12 \%$ in model 1 . Overall, the proportion of subjects classified correctly in this research model is quite good, at $75.49 \%$. 
Table 2. The sensitivity value

\begin{tabular}{|l|c|c|}
\hline \multicolumn{1}{|c|}{ Model 1 } & \multicolumn{2}{c|}{ Response Observation } \\
\hline Response prediction & Fraud & Non-Fraud \\
\hline \multicolumn{1}{|c|}{ Fraud } & 426 & 169 \\
\hline \multicolumn{1}{|c|}{ Non-fraud } & 260 & 895 \\
\hline Sensitivity & $62.10 \%$ & \\
\hline Specificity & $84.12 \%$ \\
\hline Correctly classified & $75.49 \%$ \\
\hline
\end{tabular}

The sample consists of 1750 firm-year observations for the period 2016 to 2020, with all industry sectors except the financial industry.

The study's findings indicate that the rationalization of directors affects the indications of the occurrence of FFS both for model 1 and model 2 . Companies that perform FFS as a whole and companies that perform FFS on some aspects of the financial statements consider behaviour to justify manipulating financial statements and trying to cover it up by changing the external auditor. The occurrence of audit failures and litigation increases after the change of auditors because they can occur as an effort to eliminate traces of fraud found by previous auditors [9]. This finding means accepting H4 [17], [33], [41]. Change of auditors is seen as a way for directors to eliminate traces of their manipulation where auditors take longer to detect FFS, which means the more often the company changes auditors, the greater the indications that the company is doing FFS. Although POJK Number 13 of 2017 regulates external audit tenure, this does not mean that the company replaces auditors only because it is limited to the maximum period of auditor work and an opportunity to conduct FFS.
External auditors have no relationship and have no interest in a business, so professional judgment is based on actual findings during the audit process [17]. Thus, the board of directors cannot cooperate with external auditors to hide FFS because the auditors adhere to their professional code of ethics in the form of independence. So, the board of directors tries to limit the external auditor to having limited information so that they cannot check the confidential information of the board of directors. The best way is to change auditors every year and not wait for the maximum time limit for auditor tenure.

On the other hand, this study found contradictory findings. Stimulus affects FFS occurrence when measured using the M-core, while the probability causes an indication of FFS when measured using OMI; means that $\mathrm{H} 1$ and $\mathrm{H} 3$ are partially accepted.

Stimulus arises when the company's FCF is available in large quantities. So far, FCF is associated with the efficiency of the company's investments and very rarely associated with the possibility of FFS. FCF shows its internal funding capability regarding how well the company can finance expansion and operations from its funds [21]. Shareholders benefit from the company's cash [42], while the directors will lose if the cash available in the company is distributed to shareholders. Directors are stimulated/stimulated to turn the FCF into their assets by doing FFS. However, this happens when FFS is measured using M-score and not OMI, meaning that only companies indicated to perform FFS in various elements of financial statements that use FCF to perform FFS. At the same time, companies that only manipulate specific parts of the financial statements do not make FCF a stimulus to do FFS.

Table 3. Regression's Result

\begin{tabular}{|c|c|c|c|c|}
\hline \multirow{3}{*}{ Variable } & \multirow{2}{*}{\multicolumn{2}{|c|}{$\begin{array}{c}\text { Logit Regression } \\
\text { Model } 1\end{array}$}} & \multirow{2}{*}{\multicolumn{2}{|c|}{$\begin{array}{c}\text { OLS Regression } \\
\text { Model } 2\end{array}$}} \\
\hline & & & & \\
\hline & Coef & Sig. & Coef & Sig. \\
\hline Const & .0983187 & & .3631843 & \\
\hline STI & 1.219 .673 & $0.036^{\star *}$ & $7.55 e-10$ & 0,310416667 \\
\hline KAP & -.903723 & 0,271527778 & -.0023381 & 0,527777778 \\
\hline PEL & 1.005 .212 & 0,470138889 & .0016254 & $0.031^{\star \star}$ \\
\hline RAS & 3.353 .913 & $0.000^{\star * \star}$ & .0199652 & $0.010^{\star *}$ \\
\hline EGO & -.9792212 & 0,093055556 & .0002512 & 0,539583333 \\
\hline KOL & 1.029 .731 & 0,370138889 & .0036544 & 0,091666667 \\
\hline FSP & 4.676 .592 & $0.000^{* * *}$ & -.0000306 & 0.064 \\
\hline
\end{tabular}




\begin{tabular}{|c|l|l|l|l|}
\hline ROA & 1.083 .199 & $0.000^{* * *}$ & -.0251437 & $0.040^{* *}$ \\
\hline ROE & -.9767555 & 0,155555556 & -.0001588 & $0.000^{* * *}$ \\
\hline MNG & 1.183 .991 & 0,390972222 & -.0079422 & 0,418055556 \\
\hline LEV & -.5985514 & $0.000^{* * *}$ & .002391 & $0.000^{* * *}$ \\
\hline R2 & 0,264583333 & & 0.018 & \\
\hline $\begin{array}{c}\text { Firm-year } \\
\text { effect }\end{array}$ & Yes & & Yes & \\
\hline \begin{tabular}{c} 
The \\
\hline
\end{tabular}
\end{tabular}

The sample consists of 1750 firm-year observations for the period 2016 to 2020 , with all industry sectors except the financial industry. $* * * p<0.01 ; * * p<0.05 ; * \mathrm{p}<0.1$

Probability is proven not to affect the occurrence of FFS when measured using the M - score, while it is proven to affect the event of FFS when measured using OMI. Opportunities to perform FFS can be done at any time through daily transactions, utilizing financial posts that have the potential to be manipulated, namely by using sales transactions in accounts receivable. Changes in the accounts receivable ratio do not trigger directors to commit fraud [43]. One of the causes of FFS is the difference in the timing of the recognition of a transaction, one of which is a sales transaction whose payment is paid at a later date. However, this research data shows that the average company has a ratio of sales in accounts receivable each year of $2.4 \%$. This means that only a few companies have sales transactions whose recognition can be manipulated. The increase in the receivables ratio each year does not indicate a drastic change, which means the board of directors does not falsify or modify the company's day-to-day transactions to become an opportunity to conduct FFS. This finding is not in line with the upper echelon theory, which emphasizes that directors make decisions that benefit themselves based on their personality or background. In contrast to the findings of $\mathrm{H} 1$, the probability of being the cause of the indication of the occurrence of FFS when measured using OMI while not causing the event of FFS when measured using the M-score.

On the other hand, the capabilities of the board of directors, arrogance, and collusion by the board of directors were not the cause of the company's FFS when measured using the M-score and OMI. The capability of the board of directors means its ability to manage the company so that it performs well. Still, when its performance does not meet expectations and is unable to show its capability to manage the company, its position will be replaced. The change of directors does not necessarily mean that the company is trying to hide its fraudulent scheme because one of the common reasons for the change of directors is to improve the company's performance by having more competent personnel [41], [33]. Directors who change every year can also be used to maintain the quality of the company's performance. Changes in the composition of directors are generally carried out because there are clear reasons and are disclosed in the company's annual report the composition of directors agreed by all stakeholders, whether there is a change or not, it has become part of the general agreement, which is not hidden.

The arrogance of the board of directors, which can be shown by examining the remuneration received by the board of directors, does not indicate the occurrence of FFS. The reason is that the size of compensation is not compared to the size of the board of directors; the larger the size of the board of directors is usually followed proportionally with ample remuneration so that changes in the remuneration received by the directors do not affect the occurrence of FFS. Another reason is that remuneration is usually determined and agreed upon at the GMS, making it challenging to include personal interests. All company stakeholders will decide upon the nominal amount. In addition, collusion does not affect the occurrence of FFS within the company because the average company in Indonesia controls RPT well, as evidenced by the percentage of RPT made by the company, which is $23.6 \%$ of its equity. The RPT is not used as a means of transferring directors' wealth and rejects the findings of [9], [17] and [38]. This finding could be since companies in Indonesia implement efficient RPT compared to abusive RPT, and RPT is more efficient with better transaction disclosure.

\subsection{Additional Test}

By completing a descriptive analysis of OMI, we can rank the sectors that often perform FFS and what elements in the financial statements are manipulated. This study also performs additional analysis by observing which elements in the financial statements are often used as sources for directors to conduct FFS on companies in Indonesia. Table 4 shows how often companies perform FFS on specific items in the financial statements. The table shows that among the elements contained in $\mathrm{t} h \mathrm{~h}$ e $\mathrm{M}$-score indicator, the most frequently used by companies to be manipulated is DEPI which is a depreciation index ratio. The ratio compares the current year's depreciation rate and the 
previous year's. A slower depreciation rate may indicate a higher valid life revision or the adoption of an income-friendly depreciation method [15].

The assessment of the economic life of the company's assets uses estimates that can be adjusted to the company's strategy so that it can be manipulated more quickly and more challenging to detect. This finding is supported by [44] argument, which states DEPI, DSR, AQI, SGAI, and LEVI as elements that influence manipulator companies to perform FFS. On the other hand, the aspect rarely used to manipulate financial statements is ACCRUAL, a ratio to measure management's discretionary accounting policies, which are translated into earnings changes.

Table 4. Ranking OMI on Each M-score's Element

\begin{tabular}{|c|c|c|c|c|c|c|}
\hline \multirow{2}{*}{ Element } & \multicolumn{5}{|c|}{ Ranking per Year } & \multirow{2}{*}{ Ranking All } \\
\hline & 2016 & 2017 & 2018 & 2019 & 2020 & \\
\hline DSR & 1 & 2 & 2 & 4 & 2 & 2 \\
\hline GMI & 5 & 7 & 8 & 6 & 6 & 7 \\
\hline AQI & 2 & 3 & 3 & 2 & 5 & 3 \\
\hline SGI & 6 & 5 & 6 & 8 & 8 & 6 \\
\hline DEPI & 3 & 1 & 1 & 1 & 1 & 1 \\
\hline SGAI & 4 & 6 & 7 & 3 & 3 & 4 \\
\hline ACCRUAL & 7 & 7 & 5 & 7 & 7 & 8 \\
\hline LEVI & 5 & 4 & 4 & 5 & 4 & 5 \\
\hline
\end{tabular}

This study also ranks which sectors are often indicated to carry out FFS. The descriptive data in Table 5 shows that the cyclical sector is the sector that is revealed to be the most frequent in performing FFS. The cyclical sector has the most significant number of companies in Indonesia compared to other industries.
The cyclical sector can also be a company that produces goods or services purchased when the economy is up or booming. Macroeconomic conditions and the business cycle affect this sector's income, making it more vulnerable to FFS. On the other hand, the sector that rarely performs FFS is the technology sector because the few companies observed in this study are the least.

Table 5. Ranking OMI on Each Industries

\begin{tabular}{|c|c|c|c|c|c|c|}
\hline \multirow{2}{*}{ Element } & \multicolumn{5}{|c|}{ Ranking per Year } & \multirow{2}{*}{ Ranking All } \\
\hline & 2016 & 2017 & 2018 & 2019 & 2020 & \\
\hline Basic & 3 & 2 & 3 & 2 & 3 & 3 \\
\hline Cyclical & 1 & 1 & 2 & 1 & 1 & 1 \\
\hline Non-cyclical & 2 & 3 & 1 & 3 & 2 & 2 \\
\hline Energy & 4 & 5 & 4 & 4 & 4 & 4 \\
\hline Health & 8 & 8 & 8 & 9 & 8 & 8 \\
\hline Industrial & 7 & 7 & 7 & 6 & 7 & 7 \\
\hline Infrastructure & 6 & 6 & 6 & 7 & 6 & 6 \\
\hline Property & 5 & 4 & 5 & 5 & 5 & 5 \\
\hline Technology & 10 & 9 & 10 & 10 & 10 & 10 \\
\hline Logistic & 9 & 10 & 9 & 8 & 9 & 9 \\
\hline
\end{tabular}

The sample consists of 1750 firm-year observations for the period 2016 to 2020, with all industry sectors except the financial industry. 


\section{CONLUSION}

This study compares the effect of the elements in the fraud hexagon on FFS occurrence. This study also conducted an additional test using OMI to strengthen the findings obtained from the Beneish M-score model.

The results showed that it produced slightly different findings when FFS was measured using two different measurements. The similarity of the findings of this study is that rationalization causes an indication of the occurrence of FFS, both measured using the Mscore and OMI. On the other hand, the stimulus can affect the sign of the FFS event when measured using the M-score. In contrast, the opportunity can affect the indication of FFS occurrence when measured using the OMI. Capabilities, arrogance, and collusion by the directors do not affect the occurrence of FFS in the company.

This study also proves which elements in the financial statements are often used to perform FFS. We find evidence that DEPI is the most frequently used to perform FFS, which means that companies often revise the life of assets to get a smaller burden. On the other hand, the sector that is indicated to conduct FFS frequently is the cyclical consumer sector. This finding provides an essential urgency that impairment of fixed assets is significant to minimize the occurrence of FFS because it is proven by measuring the estimated depreciation of assets that the board of directors has the opportunity to perform FFS. This finding provides a novelty that previous researchers have never studied and developed the OMI approach [16].

This study has limitations where the observed companies are only listed on the IDX, so it cannot be generalized to other countries. Although this study examines the indications of companies doing FFS, it is possible that the indications assessed using the $\mathrm{M}$ score do not match the actual conditions because they are only probabilities. In addition, the unequal number of samples per industrial sector also affects the ranking of industrial sectors that perform FFS based on OMI, causing research bias. This study failed to prove that collusion affects FFS occurrence so that future research can develop a collusion framework in FFS. Future research can test the fraud hexagon model using different measurements compared to previous studies, as has been done in this study. In addition, this study proves that measuring FFS using the M-score and OMI; there are differences which further research can further elaborate on the use of OMI, which is still rarely studied. Further research can also elaborate on the findings of this hexagon fraud by comparing conditions during the Covid-19 pandemic.

\section{ACKNOWLEDGMENTS}

This research was supported by the Indonesian Education Scholarship Program (BPI) of the Lembaga Pengelola Dana Pendidikan (LPDP).

\section{REFERENCES}

[1] PwC, "Fighting fraud: A never-ending b a tt le PwC's Global Economic Crime and Fraud Survey 2020," PWC Fraud Surv., pp.1-14, 2020, [Online]. Available: www.pwc.com/fraudsurvey.

[2] P. Craja, A. Kim, and S. Lessmann, "Deep learning for detecting financial statement fraud," Decis. Support Syst., vol. 139, no. May, p. 113421, 2020, doi: 10.1016/j.dss.2020.113421.

[3] Association of Certified Fraud Examiners, "Report to the Nations on Occupational Fraud and Abuse: 2020 Global Fraud Study," Assoc. Certif. Fraud Exam. Inc., p. 88, 2021, [Online]. Available: https://www.acfe.com/report-to-thenations/2020/.

[4] R. Aviantara, "Scoring the financial d ist ress and the financial statement fraud of Garuda Indonesia with «DDCC» as the financial solutions," J. Model. Manag., 2021, DOI: 10.1108/JM2-01-2020-0017.

[5] G. L. Vousinas, "Advancing theory of fraud: the S.C.O.R.E. model," J. Financ. Crime, vol. 26, no. 1, pp. 372-381, 2019, doi:10.1108/JFC12-2017-0128.

[6] T. A. A. Koomson, G. M. Y. Owusu, R. A. Bekoe, and M. Oquaye, "Determinants of asset misappropriation at the work place: $\mathrm{t} \mathrm{h}$ e moderating role of perceived strength of internal controls," J. Financ. Crime, vol. 27, no. 4, pp. 1191-1211, 2020, doi: 10.1108/JFC-042020-0067.

[7] S. U. Sa'id and K. S. Abas Azmi, "Challenges of combating fraudulent practices: evidence from Nigerian public sector," J. Financ. Crime, 2020, DOI: 10.1108/JFC-04-2020-0075.

[8] A. I. Zahari, J. Said, and N. Muhamad, "Public sector fraud: the Malaysian perspective," $J$. Financ. Crime, 2021, doi: 10.1108/JFC-012021-0013.

[9] B. L. Handoko and D. Tandean, “An Analysis of Fraud Hexagon in Detecting Financial Statement Fraud (Empirical Stu d y o f Listed Banking Companies on Indonesia Stock Exchange for Period 2017-2019)," AC M Int. Conf. Proceeding Ser., pp. 93-100, 2021, doi: 
10.1145/3457640.3457657. SMEs," Ratio Math., vol. 28, pp. 65-83, 2015.

[10] J. Maccarthy, "Using Altman Z-score and Beneish M-score Models to Detect Financial Fraudand Corporate Failure: A Case Study of Enron Corporation,"Int. J. Financ.Account., vol. 6, no. 6, pp. 159-166, 2017, doi: 10.5923/j.ijfa.20170606.01.

[11] C. Corsi, D. Di Berardino, and T. Di Cimbrini, "Beneish M- score and detection of earnings management in Italian SMEs," Ratio Math., vol. 28, pp. 65-83, 2015.

[12] W. Lu and X. Zhao, "Research and improvement of $\mathrm{f}$ rau d identification model of Chinese A-share listed companies based on Mscore," J. Financ. Crime, vol. 28, no. 2, pp. 566- 579, 2020, doi: 10.1108/JFC-12-20190164.

[13] N. R. Shaari Anaghiz, J. S. Sedghiani, and A. Khorasani, "Investigating and Implementing the Accuracy of the Results of Beneish and Modied Beneish Models Based on Iran's Economic Environment, in Detecting and Revealing Fraudulent Financial Reporting.," Financ. Manag. Perspect., vol. 18, pp. 105123, 2017.

[14] L. Svabova, K. Kramarova, J. Chutka, and L. Strakova, "Detecting earnings manipulation and fraudulent financial reporting in Slovakia," Oeconomia Copernicana, vol. 11, no. 3, pp. 485-508, 2020, doi: 10.24136/OC.2020.020.

[15] G. Kukreja, S. M. Gupta, A. M. Sarea, and S. Kumaraswamy, "Beneish M-score and Altman Z-score as a catalyst for corporate fraud detection," J. Invest. Compliance, vol. 21, no. 4, pp. 231-241, 2020, doi: 10.1108/joic-09-20200022.

[16] M. S. Hasan, N. Omar, P. Barnes, and M. Handley-Schachler, "A cross-country study on manipulations in financial statements of listed companies Evidence from Asia," J. Financ. Crime, vol. 24, no. 4, pp. 656-677, 2017, doi: 10.1108/JFC-07-2016-0047.

[17] F. A. Fitri, M. Syukur, and G. Justisa, "Do the fraud triangle components motivate fraud in Indonesia?," Australas. Accounting, Bus. Financ. J., vol. 13, no. 4, pp. 63-72, 2019, DOI: 10.14453/aabfj. v13i4.5.

[18] Meiryani, M. A. Amri, J. Sudrajat, and I. E. Riantono, "The effect of financial target and financial stability on fraudulent financial statements," J. Crit. Rev., vol. 7, no. 6, pp. 692699, 2020, doi: 10.31838/jcr.07.06.121.

[19] M. P. Sari, N. Pramasheilla, Fachrurrozie, T. Suryarini, and I. D. Paimuigkas, "Analysis of fraudulent financial reporting with the role of KAP big four as a moderation variable:
Crowe's fraud's pentagon theory," Int. J. Financ. Res., v o 1. 11, no. 5, pp. 180-190, 2020, doi:10.5430/IJFR.V11N5P180.

[20] Y. Yulianti, S. R. Pratami, Y. S. Widowati, a nd L. Prapti, "Influence of fraud pentagon toward fraudulent financial reporting in Indonesia an empirical study on financial sector listed in Indonesian stock exchange," Int. J. Sci. Technol. Res., vol. 8, no. 8, pp. 237-242, 2019.

[21] Nindito, "Financia 1 statement fraud: Perspective of the Pentagon Fraud model in Indonesia," Acad. Account. Financ. Stud. J., vol. 22, no. 3, pp. 1-9, 2018.

[22] E. García -Meca, M. C. Ramón-Llorens, and J. Martínez-Ferrero, "Are narcissistic CEOs more tax aggressive? The moderating role of internal audit committees," J. Bu s. Res., vol. 129, no. July 2020, pp. $223-235,2021$, doi: 10.1016/j.jbusres.2021.02.043.

[23] D. C. Hambrick and P. A. Mason, "UppernEchelons: The Organization as a Reflection of Its Top Managers.," Acad. Manag. Rev., v o 1. 9, no. 2, pp. 193-206, 1984, doi:10.5465/amr.1984.4277628.

[24] D. C. Hambrick, "Upper echelons theory: An update," Acad. Manag. Rev., vol. 32, no. 2, pp. 334-343,2007, 10.5465/AMR.2007.24345254

[25] J. Dorminey, A. Scott Fleming, M. J. Kranacher, and R. A. Riley, "The evolution of fraud theory," Issues Account. Educ., vol. 27, no. 2, pp. 555-579, 2012, doi: 10.2 308/ iace 50131 .

[26] J. Dorminey, S. Fleming, M. Kranacher, a n d R. Riley, "Beyond the fraud triangle," $C P A J$., vol. 80, no. 7, pp. 17-23, 2010.

[27] Z. Fakhroni, I. Ghozali, P. Harto, and E. N. A. Yuyetta, "Free cash flow, investment inefficiency, and earnings management: Evidence from manufacturing firms list ed on the Indonesia stock exchange," Invest. Manag. Financ. Innov., vol. 15, no. 1, pp. 299-310, 2018, DOI: 10.21511/imfi.15(1).2018.25.

[28] A. A. Christie and J. Zimmerman L., "Efficient and opportunistic choices of accounting procedures: Corporate control contests," Account. Rev., pp. 539-566., 1994.

[29] D. Ramadhan, "Root Cause Analy sis Using Fraud Pentagon Theory Approach (a Conceptual Framework)," Asia Pacific Frau d J., vol. 5, no. 1, p. 118, 2020, doi: 10.21532/ apfjournal. v5i1.142.

[30] S. P. Sari and N. K. Nugroho, "Financial Statements Fraud dengan Pendekatan Vousinas Fraud Hexagon Model: Tinjauan pada Perusahaan Terbuka di I n don esia 26," 
IHTIFAZ Islam. Econ. Financ. Banking (ACI IJIEFB), pp. 1-22, 2020.

[31] H. Dalnial, A. Kamaluddin, Z. M. Sanusi, and K. S. Khairuddin, "Accountability in Financial Reporting: Detecting Fraudulent Firms," Procedia - Soc. Behav. Sci., vol. 145, pp. 61-69, 2014, doi: https://doi.org/10.1016/j.sbspro.2014.06.011.

[32] D. R. Cressey, Other People's Money: The Social Psychology of Embezzlement. New York: The Free Press, 1953.

[33] Y. Septriyani and D. Handayani, "Mendeteksi Kecurangan Laporan Keuangan dengan Analisis Fraud Pentagon," J. Akuntansi, Keuang. dan Bisnis, vol. 11, no. 1, pp. 11-23, 2018, [Online]. Available: http://jurnal.pcr.ac.id.

[34] H. Umar, D. Partahi, and R. B. Purba, "Fra ud diamond analysis in detecting fraudulent financial report," Int. J. Sci. Technol. Res., vol. 9, no. 3, pp. 6638-6646, 2020.

[35] H. Crowe, "Why the fraud triangle is no longer enough," 2011. no. 4, 2018, doi: 10.1108/CG07-2017-0148.

[36] A. Agnihotri and S. Bhattacharya, "CEO narcissism and internationalization by Indian firms," Manag. Int. Re., v o 1. 59, no. 6, pp. 889918, 2019.

[37] N. Christian, Y. Z. Basri, and W. Arafah, "Analysis of Fraud Pentagon to Detecting Corporate Fraud in Indonesia," Int. J.

, doi: 10.1108/JFC-11-20 14-005.
[38] A. Habib, A. H. Muhammadi, and H. Jiang, "Political connections, related party transactions, and audit or ch o ice: Evidence from Indonesia," J. Contemp. Account. Econ., v ol. 13, no. 1, pp. 1-19, 2017, doi: 10.1016/j.jcae.2017.01.004

[39] C. J. Skousen, K. R. Smith, and C. J. Wright Detecti ng a nd Predicting Financial Statement Fraud: The Effectiveness of The Fraud Triangle and SAS No. 99 in Corporate Governance and Firm Performance, vol. 32, no. 3. 2009

[40] A. Widarjono, Ekonometrika: Pengantar dan Ap likasi nya. 2018.

[41] B. L. Handoko and Natasya, "Fraud diamond model for fraudulent financial statement detection," Int. J. Recent Technol. Eng., vol. 8, no. 3, pp. 6865-6872, 2019, doi: 10.35940/ijrte.C5838.098319.

[42] D. Asante-Darko, B. Adu Bonsu, S. Famiyeh, A. Kwart en g, and Y. Goka, "Governance structures, cash holdings and firm value on the Ghana Stock Exchange," Corp. Gov., vol. 18,

[43] I. Didin, "Pengaruh stabilitas keuangan, kondisi industri dan tekanan eksternal terhadap kecurangan laporan keuangan," J. Kaji. Akunt., vol. 2, no. 1, pp. 82-97, 2018.

[44] S. Repousis, "Using Beneish model to detect corporate financial statement fraud in Greece," J. Financ. Cri me, v o 1. 23, no. 4, pp. 1063 1073, 2016 